\title{
Depletion of Cholinergic Amacrine Cells by a Novel Immunotoxin Does Not Perturb the Formation of Segregated On and Off Cone Bipolar Cell Projections
}

\author{
Emine Günhan, ${ }^{*}$ Prabhakara V. Choudary, ${ }^{*}$ Thomas E. Landerholm, and Leo M. Chalupa \\ Section of Neurobiology, Physiology and Behavior, Division of Biological Sciences and Department of Ophthalmology, \\ School of Medicine, University of California, Davis, California 95616
}

Cone bipolar cells are the first retinal neurons that respond in a differential manner to light onset and offset. In the mature retina, the terminal arbors of On and Off cone bipolar cells terminate in different sublaminas of the inner plexiform layer (IPL) where they form synapses with the dendrites of On and Off retinal ganglion cells and with the stratified processes of cholinergic amacrine cells. Here we first show that cholinergic processes within the On and Off sublaminas of the IPL are present early in development, being evident in the rat on the day of birth, $\sim 10 \mathrm{~d}$ before the formation of segregated cone bipolar cell axons. This temporal sequence, as well as our previous finding that the segregation of On and Off cone bipolar cell inputs occurs in the absence of retinal ganglion cells, suggested that cholinergic amacrine cells could provide a scaffold for the subsequent in-growth of bipolar cell axons. To test this hypothesis directly, a new cholinergic cell immunotoxin was constructed by conju- gating saporin, the ribosome-inactivating protein toxin, to an antibody against the vesicular acetylcholine transporter. A single intraocular injection of the immunotoxin caused a rapid, complete, and selective loss of cholinergic amacrine cells from the developing rat retina. On and Off cone bipolar cells were visualized using an antibody against recoverin, the calciumbinding protein that labels the soma and processes of these interneurons. After complete depletion of cholinergic amacrine cells, cone bipolar cell axon terminals still formed their two characteristic strata within the IPL. These findings demonstrate that the presence of cholinergic amacrine cells is not required for the segregation of recoverin-positive On and Off cone bipolar cell projections.

Key words: cholinergic amacrine cells; immunotoxin; bipolar cells; On/Off pathways; visual development; retinal development; recoverin
A common feature of all sensory modalities is the segregation of different functions into separate pathways or modules along the neural axis. In the case of the visual system, such an organization has been documented for eye-specific connections and orientation selective cells, as well as On and Off channels. A major challenge for developmental neurobiologists has been to gain a better understanding of the cellular and molecular mechanisms underlying the formation of such distinct functional pathways. Most of this effort has been directed at studying the formation of eye-specific projections and orientation columns at the level of the visual cortex (Wiesel, 1982; Singer, 1995). A number of recent studies have been concerned with the development of segregated On and Off retinal pathways (Chalupa et al., 1998; Leamey et al., 1998).

In the mature retina, increments and decrements of light are signaled by neurons that form their synaptic contacts within different sublaminas of the inner plexiform layer (IPL). This organization begins with On and Off cone bipolar cells that depolarize or hyperpolarize to light, with the axon arbors of these retinal interneurons innervating the stratified dendrites of On and Off retinal ganglion cells (Famiglietti and Kolb, 1976; Nelson et al., 1978). Another cell class with processes restricted to either

\footnotetext{
Received Oct. 12, 2001; revised Dec. 11, 2001; accepted Dec. 21, 2001.

This work was supported by EY03991 and CORE grants from the National Eye Institute. We thank Dr. Alexander Dizhoor, Wayne State University, for the generous gift of recoverin antibody, and Nadia Aldret, Jill Frederiksen, Michael Giese, Andrew Huberman, David Lindgren, and Nicole Tetreault for technical assistance. *E.G. and P.V.C. contributed equally to this work.

Correspondence should be addressed to Leo M. Chalupa, Section of Neurobiology, Physiology and Behavior, 1 Shields Avenue, University of California, Davis, CA 95616. E-mail: lmchalupa@ucdavis.edu.

Copyright (C) 2002 Society for Neuroscience $\quad 0270-6474 / 02 / 222265-09 \$ 15.00 / 0$
}

the On or Off sublaminas of the IPL are cholinergic amacrine cells, also termed starburst amacrine cells (Famigletti, 1992). These cells have been implicated in various developmental functions (for review, see Zhou, 2001), including neuronal genesis, growth, migration, and synaptogenesis (Redburn and RoweRedleman, 1996), as well as the propagation of retinal waves of activity (Feller et al., 1996; Zhou, 1998; Zhou and Zhoa, 2000).

In contrast to the separation of On and Off pathways observed in the adult retina, early in development the dendrites of retinal ganglion cells ramify throughout the IPL (Maslim and Stone, 1988; Bodnarenko et al., 1995). Immature ganglion cells with multistratified dendrites respond to light onset as well as light offset, which suggests that these neurons are transiently innervated by On and Off cone bipolar cells (Wang et al., 2001). Treatment of the developing retina with L-2-amino 4-phosphonobutyrate, a drug that prevents the release of glutamate by On cone and rod bipolar cells in the mature retina, has been shown to prevent the normal stratification of ganglion cell dendrites (Bodnarenko and Chalupa, 1993; Bodnarenko et al., 1995; Bisti et al., 1998). These results suggest that glutamate release by bipolar cells regulates this developmental process.

Less is known about the development of bipolar cell projections. It has been shown that On and Off cone bipolar cell axons form their segregated strata within the IPL in a remarkably specific manner (Miller et al., 1999; Günhan-Agar et al., 2000) and that the segregation of On and Off cone bipolar axon terminals occurs even in the absence of retinal ganglion cells (GünhanAgar et al., 2000). This has led to the suggestion that the stratified processes of cholinergic amacrine cells might act as a scaffold for 
the segregated in-growth of cone bipolar cell axons (GünhanAgar et al., 2000). A direct way to test this hypothesis is to assess the effects of depleting cholinergic amacrine cells on the subsequent development of cone bipolar cell projection patterns.

To address this issue, in the present study we constructed a novel immunotoxin designed to target cholinergic amacrine cells. Here we show that this cholinergic immunotoxin causes a rapid, virtually complete, and selective loss of cholinergic amacrine cells from the developing retina. (The toxin that we constructed is also effective in eliminating cholinergic neurons from the basal forebrain.) Using this novel immunotoxin, we show that recoverin-positive On and Off cone bipolar cells form segregated projections in the complete absence of cholinergic amacrine cells. Thus, the cellular targets of these bipolar cells appear not to be required for the formation of this initial component of retinal On and Off pathways.

\section{MATERIALS AND METHODS}

Construction and purification of the immunotoxin. A single-step procedure was used to conjugate the protein toxin, saporin, to the goat antivesicular acetylcholine transporter (VAChT ) polyclonal antibody using 1-ethyl-3-(3-dimethylaminopropyl) carbodiimide (EDC) coupling chemistry (Davis and Preston, 1981; Nakajima and Ikada, 1995). Saporin (Sigma, St. Louis, MO) was dissolved in conjugation buffer [0.1 M 2-( $N$-morpholino) ethanesulfonic acid, $0.9 \mathrm{M} \mathrm{NaCl}, \mathrm{pH}$ 4.7] and mixed with anti-VAChT antibody (Chemicon International, Temecula, CA) in equal amounts and incubated at room temperature for $2 \mathrm{hr}$ in the presence of EDC (Pierce, Rockford, IL) following the vendor's instructions. The carbodiimide (EDC) initially reacts with the carboxyl groups available on both saporin and the IgG molecule to form active, unstable $O$-acylurea intermediates that in turn react with primary amines to form amide bonds. The formation of covalent bonds makes the antiVAChT::saporin conjugate highly stable. The immunotoxin is recovered after overnight dialysis against PBS and stored in aliquots at $-80^{\circ} \mathrm{C}$. Protein concentrations were determined by microtiter plate assay on a SpectraMax 340 spectrophotometer (Molecular Devices, Sunnyvale, CA) at $595 \mathrm{~nm}$ using the Bio-Rad Protein Assay (Bio-Rad, Hercules, CA). The immunotoxin that we constructed is available from List Biological Laboratories (Campbell, CA).

Intraocular injections. Timed-pregnant and adult Long-Evans rats were obtained from Simonsen Laboratories (Gilroy, CA). Animals were housed and bred in accordance with University of California guidelines for the use of laboratory animals. Rat pups were anesthetized by hypothermia, and intraocular injections were made using a $5 \mu \mathrm{l}$ Hamilton syringe with a 30 gauge blunt-tip needle attached to a micromanipulator. The injections were made into the temporal portion of the sclera at the level of the ora serrata. Five dilutions of the immunotoxin preparation, $700,350,70,35$, and $7 \mathrm{ng} / \mu \mathrm{l}$, were brought to a total injection volume of $2.0 \mu \mathrm{l}$ with sterile PBS. Control animals from the same litter were injected with vehicle (immunotoxin omitted), anti-VAChT antibody, saporin, keyhole limpet hemocyanin (KLH)::saporin, and goat antirabbit IgG::saporin (Chemicon International).

Antibodies. For labeling of cholinergic cells, sections were incubated with anti-VAChT or anti-choline acetyl transferase (ChAT) antibodies (Chemicon International). The size of the retina, the thickness of its layers, and the total number of cells in the ganglion cell layer were counted in tissue treated with 4',6'-diamidino-2-phenylindole (DAPI) DNA-labeling dye (Vector Laboratories, Burlingame, CA). All ganglion cells and a subset of amacrine cells in the ganglion cell layer were identified with a monoclonal antibody to parvalbumin (PARV-19, Sigma). On- and Off cone bipolar cells were labeled with a rabbit polyclonal antibody to recoverin (a generous gift from Dr. A. Dizhoor, Wayne State University, Detroit, MI), and dopaminergic amacrine cells were labeled using a sheep polyclonal antibody to tyrosine hydroxylase (Chemicon International). A third subset of cone bipolar cells along with some horizontal and ganglion cells were labeled with a monoclonal antibody to calbindin (CB-955, Sigma). The concentrations of the primary antibodies used were as follows: parvalbumin (1:1000), recoverin (1:2000), tyrosine hydroxylase (1:500), and calbindin (1:100).

Tissue preparation and immunochemistry. Animals were killed by a lethal injection (intraperitoneal) of sodium pentobarbital $(0.6 \mathrm{mg} / \mathrm{kg}$ body weight) at time points ranging from 1 to $45 \mathrm{~d}$. All but the youngest animals $(\leq 48 \mathrm{hr})$ were transcardially perfused with ice-cold saline followed by $4 \%$ paraformaldehyde (PFA). The eyecups were removed, hemisected, and post-fixed with 4\% PFA for 2-4 hr, followed by immersion in $25 \%$ sucrose solution to cryoprotect the tissue before embedding in OCT compound (Tissue Tek, Torrance, CA). Vertical sections were cut at a thickness of $10-12 \mu \mathrm{m}$ on a Leica 1900 cryostat (Bannockburn, IL) and mounted on poly-L-lysine-coated slides (Sigma). Primary antibodies were diluted in blocking solution containing normal serum, BSA, and Triton X-100 overnight at $4^{\circ} \mathrm{C}$. After several washes with PBS, the sections were incubated with fluorescent secondary antibodies (Vector Laboratories, or Molecular Probes, Eugene, OR) diluted 1:600 in PBSBSA for $1 \mathrm{hr}$ at room temperature. Alternatively, sections were incubated with biotinylated secondary antibodies (diluted 1:300 in PBS-BSA) for 1-2 hr at room temperature. After several washes with PBS-BSA, these sections were incubated with the HRP-containing ABC solution (Vector Laboratories) for $1-2 \mathrm{hr}$ at room temperature and then treated with a 0.5 $\mathrm{mg} / \mathrm{ml}$ diaminobenzidine solution in the presence of $\mathrm{H}_{2} \mathrm{O}_{2}$ for 10-30 min until a precipitate was formed at the site of antibody binding. Slides were coverslipped with Vectashield mounting media (Vector Laboratories), with or without DAPI, or with glycerol. Images were collected using a Nikon (E600) binocular microscope equipped for epifluorescence. Separately collected images using different fluorochromes were recombined in Adobe Photoshop, and the light levels were adjusted to reflect the original images.

Data analysis. The methods using transverse retinal sections to estimate the magnitude of immunolabeled cell populations have been described previously (White and Chalupa, 1991; Hutsler and Chalupa, 1995; Günhan-Agar et al., 2000). Counts of labeled cells were made in a minimum of 10 sections, taken from representative microscopic fields at $40 \times$ (including peripheral, paracentral, and central segments), and every immunopositive cell was counted. Estimates were obtained of the number of cells using well established stereological techniques as described in Günhan-Agar et al. (2000). The immunostaining pattern and cell counts obtained from the retinal sections provide an estimate of the total number of cells in each retina, the spatial distribution of these neurons across the retinal surface, and the laminar localization of the cell types within the retinal layers. In addition, the thickness of the different retinal layers was measured to provide an index of the overall dimension of the treated and control retinas. Mean cell counts from each section were compared by the Student's $t$ test, with a significance level of $p<0.05$, and are expressed as overall mean \pm SEM.

\section{RESULTS}

\section{Development of cholinergic amacrine cells}

Figure 1 shows the time course of cholinergic amacrine cell development in the postnatal retina of the rat using antibodies that recognize cholinergic-specific markers, VAChT $(A-E)$ and ChAT $(F-J)$. VAChT immunoreactivity is evident on the day of birth, postnatal day zero $(\mathrm{P} 0)$, shown in Figure $1 A$. ChAT immunoreactivity is first detectable $\sim 48 \mathrm{hr}$ later (Fig. $1 G$ ). Although VAChT labeling is primarily confined to somas in the IPL at P0, two distinct strata of cholinergic processes are clearly evident within the IPL by P2 (Fig. $1 B$ ). Both antibodies identify two bands in the IPL by P6, and by P12 the pattern of labeling is indistinguishable from that observed in the adult rat retina. The cholinergic phenotype expression in the newborn rat retina made it feasible to target cholinergic amacrine cells via their vesicular transporter as early as the day of birth.

By comparison, the formation of segregated cone bipolar cell projections occurs much later in development (Günhan-Agar et al., 2000). The photomicrographs depicted in Figure 2 underscore this difference in the developmental time course between these two populations of retinal interneurons. To visualize On and Off cone bipolar cells, we used an antibody against recoverin, the calciumbinding protein shown in green, whereas VAChT labeling of cholinergic cells is in red. $A-D$ represent progressively older ages: P0, $\mathrm{P} 6$, P12, and $\mathrm{P} 20$, respectively. Note that at $\mathrm{P} 6$, when the two strata of cholinergic processes are already clearly formed, the presumptive bipolar cells are just beginning to migrate to the inner nuclear layer, and that the segregation of On and Off cone bipolar projections is not fully formed until P12. Thus, there is a 

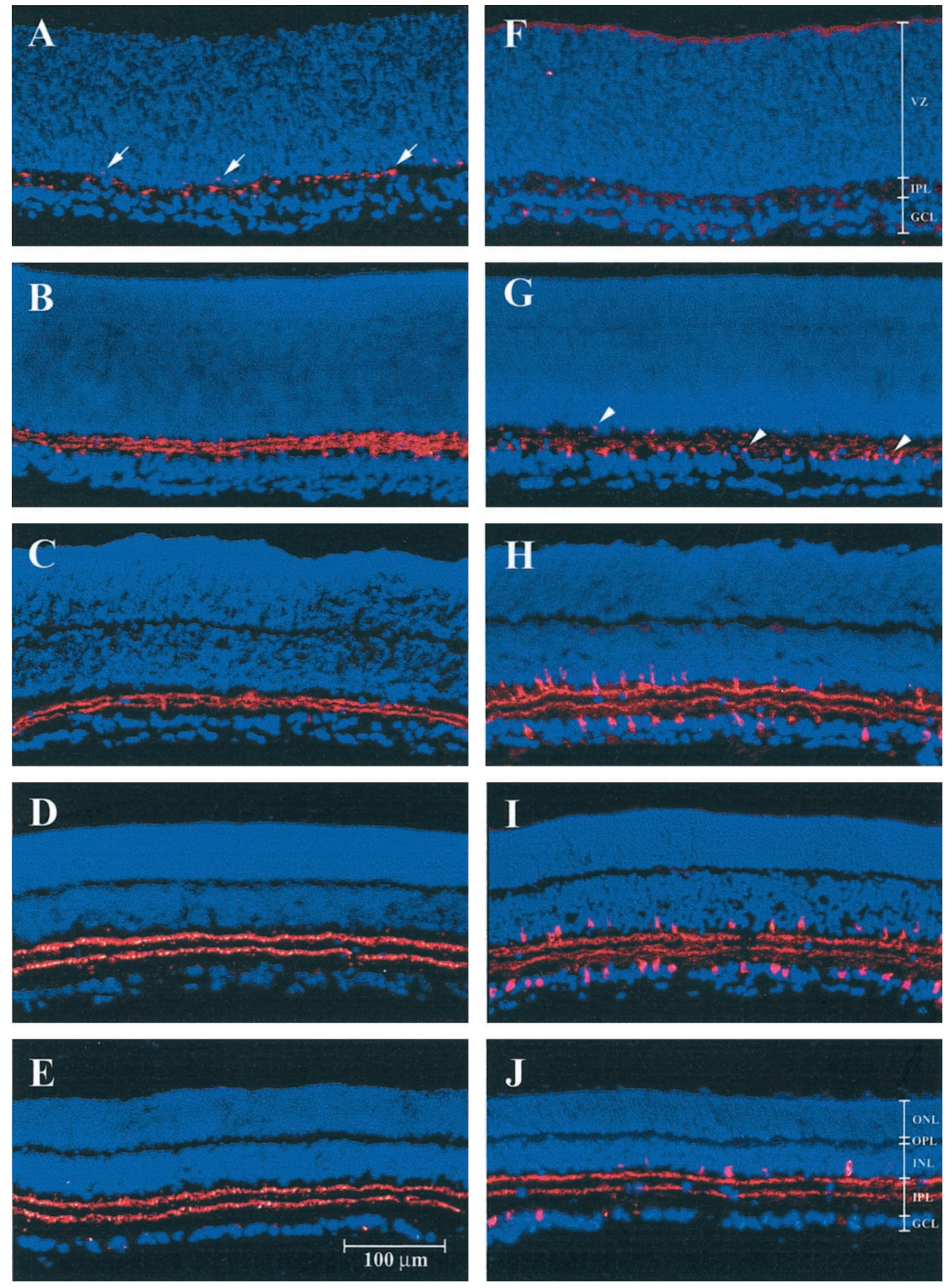

Figure 1. Cholinergic amacrine cells in the developing rat retina. The images are vertical sections of retinas with the inner, or corneal, side at the bottom of the section. VAChT antibody labeling is shown on the left, with ChAT labeling on the right (red). Sections are counterstained with DAPI nuclear stain (blue). From top to bottom, the images show protein expression on the day of birth (P0) $(A, F)$, P2 $(B, G), \mathrm{P} 6(C, H), \mathrm{P} 12(D, I)$, and in the adult $(E, J)$. The layers of the immature postnatal retina $(F)$ include the ventricular zone $(V Z)$, the inner plexiform layer $(I P L)$, and the ganglion cell layer $(G C L)$. In the mature retina $(J)$, the layers are the outer nuclear, or photoreceptor, layer $(O N L)$, the outer plexiform layer $(O P L)$, the inner nuclear layer $(I N L)$, the IPL, and the GCL. Arrows show the earliest VAChT staining at $\mathrm{P} 0(A)$, and $a r$ rowheads show the earliest ChAT staining at $\mathrm{P} 2(G)$.
7-10 d delay from the time that segregated cholinergic strata first become evident until the formation of segregated cone bipolar cell projections.

\section{Effectiveness and specificity of the cholinergic immunotoxin}

The immunotoxin used in the present studies was produced by a $2 \mathrm{hr}$ reaction of $200 \mu \mathrm{l}$ of anti-VAChT $(0.862 \mu \mathrm{g} / \mu \mathrm{l})$ with $200 \mu \mathrm{l}$ of saporin $(1.0 \mu \mathrm{g} / \mu \mathrm{l})$ in the presence of EDC. After dialysis to remove free saporin, we recovered $400 \mu \mathrm{l}$ of end product with a final concentration of $0.705 \mu \mathrm{g} / \mu \mathrm{l}$. To determine the effective dose of the immunotoxin, an in vivo retinal assay was used. A single intraocular injection of the immunotoxin in the P1 rat was assessed at several concentrations, ranging from 700 to $7 \mathrm{ng} / \mu \mathrm{l}$ (Fig. 3). Animals were killed 12-20 d later, and retinal sections were subsequently examined for the presence of cholinergic cells by ChAT labeling. At the two highest doses, the toxin-treated eyes were much smaller and appeared to have delayed development of normal layered structures relative to vehicle-treated eyes (data not shown). At the lowest dose $(7 \mathrm{ng} / \mu \mathrm{l})$, the elimination of cholinergic amacrine cells was pronounced but incomplete. Therefore, in all cases reported here we used the lowest effective dose of $35-70 \mathrm{ng} / \mu \mathrm{l}$.

Figure $4 A-D$ shows a comparison of ChAT immunoreactivity (red) in rat retinas after treatment at $\mathrm{P} 1$ with the vehicle control $(A, C)$ or toxin $(B, D)$ in animals killed at $\mathrm{P} 2(A, B)$ and $\mathrm{P} 6(C, D)$. The immunotoxin began to disrupt the morphological integrity of cholinergic amacrine cells by P2 $(B)$ so that by P6 treatment with the toxin resulted in complete elimination of ChAT immunore- 

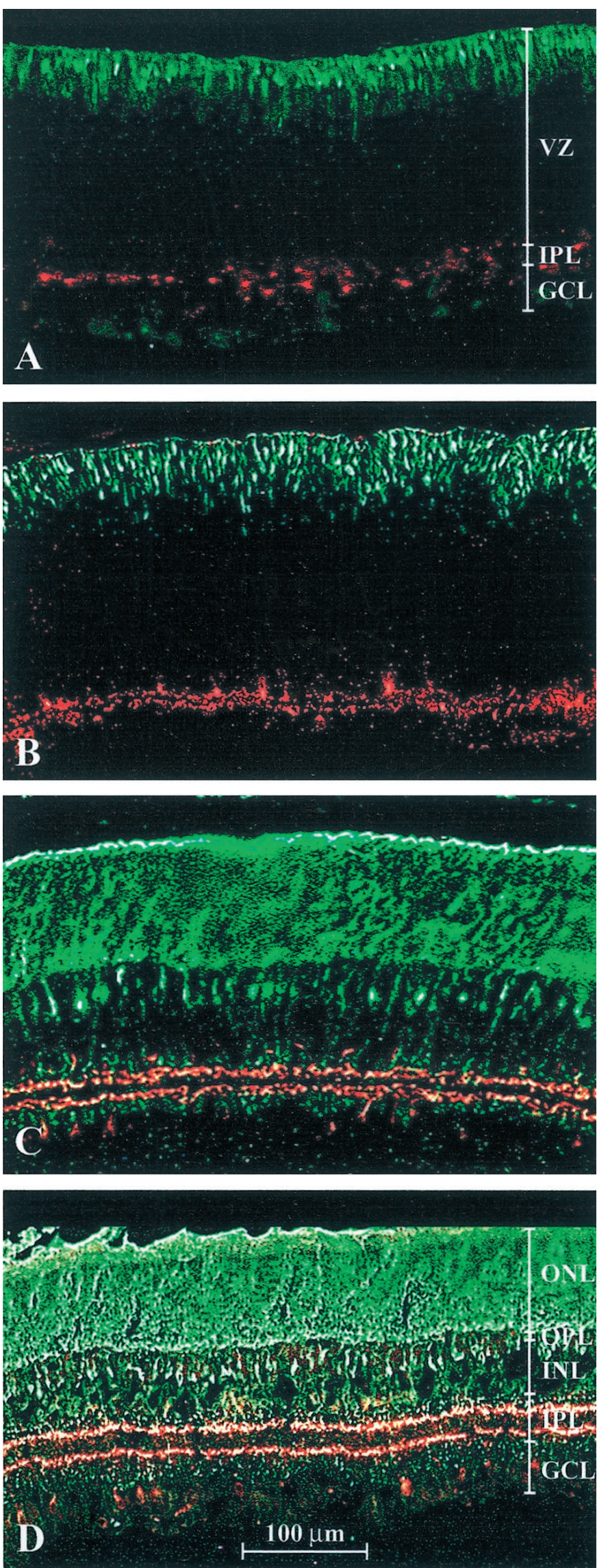

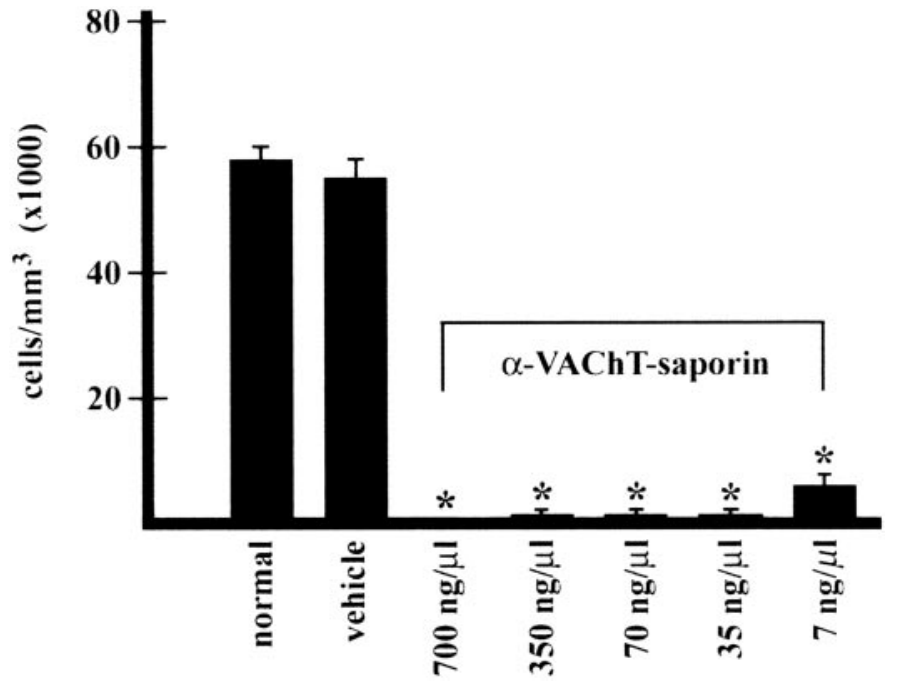

Figure 3. Determination of lowest effective dose of the immunotoxin. The vertical axis is the number of cholinergic amacrine cells per cubic millimeter of retina from morphometric analysis of ChAT immunoreactivity. The horizontal axis is the range of immunotoxin concentrations and vehicle injected in $2 \mu \mathrm{l}$ total volume at P1. Counts were made at P12-P20. Values are \pm SEM. Significance $=p<0.05 .{ }^{*} p<0.001$.

activity $(D)$. Similar losses of cholinergic amacrine cells were observed after a single treatment at P1 at all time points from P3 to P45 (data not shown).

We also assessed the effectiveness of the immunotoxin in the forebrain to establish its use for colleagues working on structures other than the retina. A single injection of $10 \mu \mathrm{l}$ directly into the medial septal nucleus of the basal forebrain in adult rats was found to dramatically deplete ChAT immunoreactivity in this structure (data not shown).

To establish the specificity of the VAChT::saporin for destroying cholinergic neurons, the effectiveness of the toxin was compared with that of control injections. Figure 5 shows a comparison of the number of cholinergic amacrine cells labeled with ChAT in animals injected with the vehicle, unconjugated anti-VAChT antibody, free saporin, and saporin conjugated to either a nonspecific antibody (goat anti-rabbit IgG) or a non-IgG-protein (KLH). Neither vehicle nor unconjugated anti-VAChT antibody appreciably affected cholinergic amacrine cell number. Saporin conjugated to either a nonspecific antibody or to KLH did not affect cholinergic amacrine cell number. However, free saporin did reduce the number of cells by $\sim 30 \%$ of untreated controls, suggesting that unconjugated saporin is capable of entering neurons and that incomplete dialysis could cause nonspecific cell death.

Retinas treated with immunotoxin or vehicle were compared with normal controls for overall size of the eyecup and thickness of the various layers. The linear diameter of treated retinas

$$
\leftarrow
$$

Figure 2. Cholinergic amacrine cells stratify before in-growth of cone bipolar cells. Shown are vertical sections of normal retinas stained with VAChT for cholinergic amacrine cells (red) and recoverin for cone bipolar cells (green). From top to bottom, the images show marker expression on $\mathrm{P} 0(A), \mathrm{P} 6(B), \mathrm{P} 12(C)$, and $\mathrm{P} 20(D)$. The layers of the immature $(A)$ and mature retinas $(D)$ are the same as in Figure 1. Note that the appearance and stratification of cholinergic amacrine cells precede the migration of cone bipolar cell bodies from the ventricular zone and the subsequent extension of their axonal processes into the IPL. 

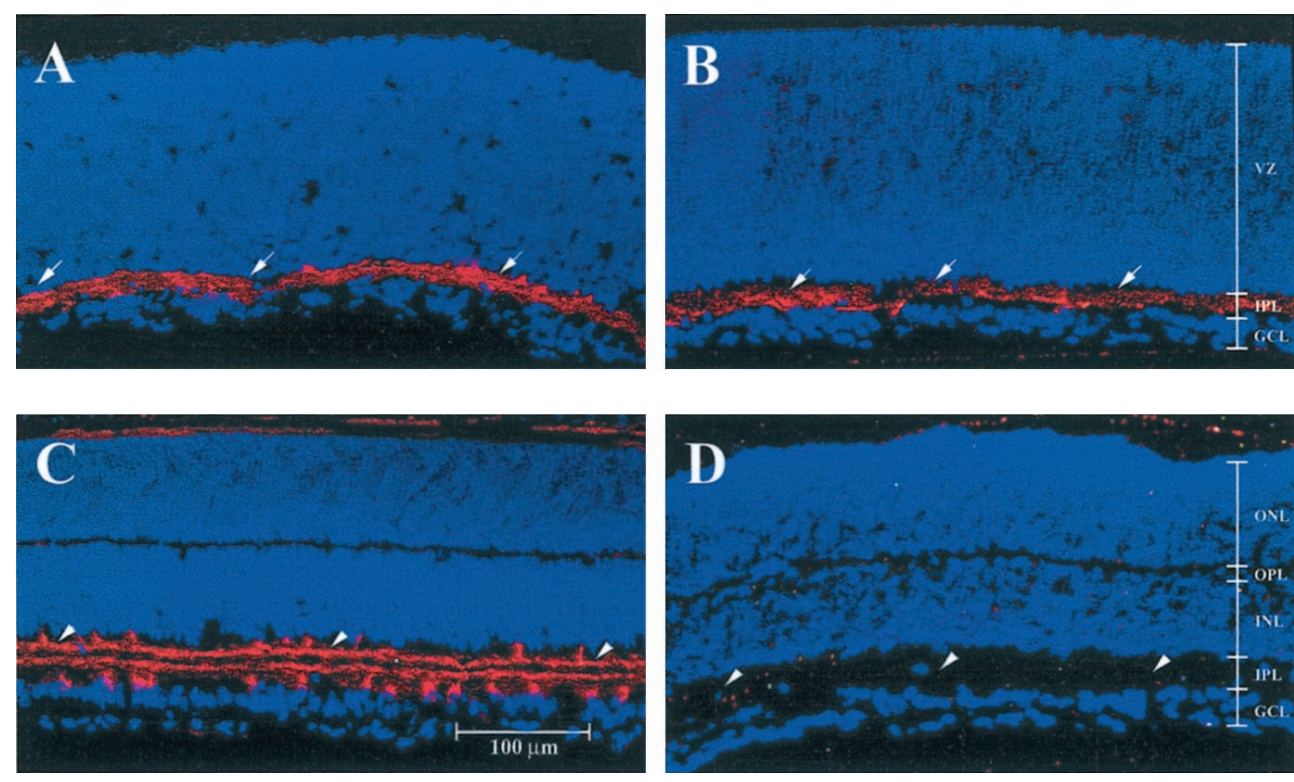

Figure 4. Elimination of cholinergic neurons in the developing retina and adult brain. Shown are vertical sections immunostained for ChAT (red) against a DAPI background (blue). Retinas were injected at P1 with vehicle (left) or immunotoxin (right). $A$ and $B$ are $\mathrm{P} 2$ retinas; $C$ and $D$ are P6 retinas. Arrows show detectible changes in ChAT immunoreactivity $24 \mathrm{hr}$ after immunotoxin injection, whereas arrowheads show complete loss of cholinergic amacrine cells by $\mathrm{P} 6$.

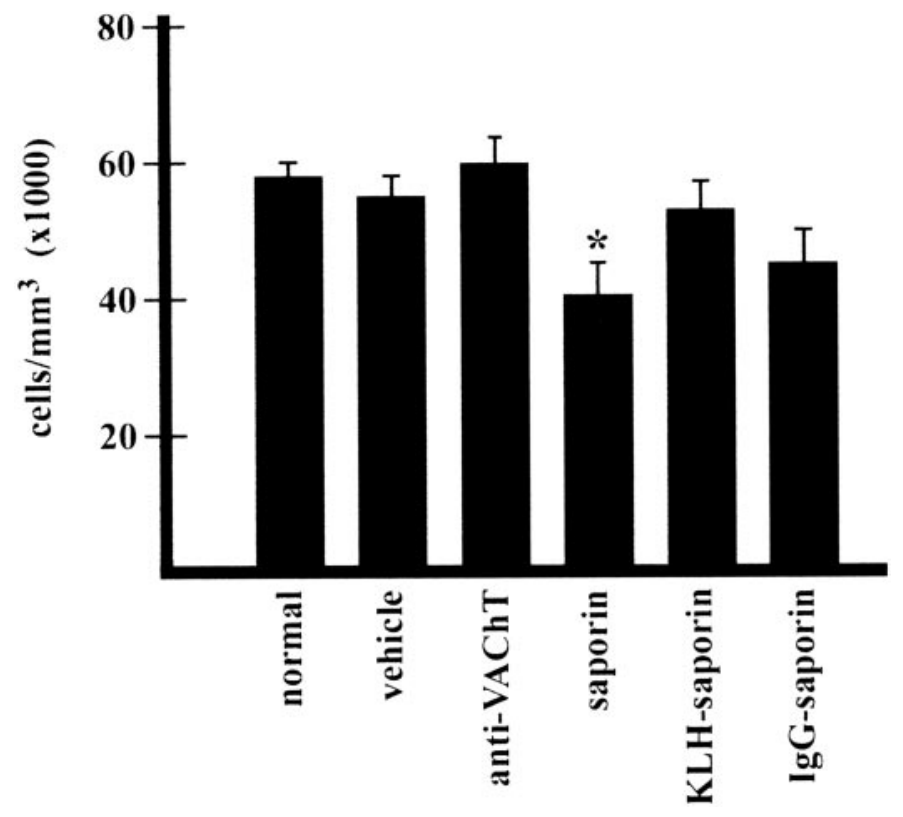

Figure 5. Control series for immunotoxin structure and function. The number of cholinergic amacrine cells labeled with ChAT (per cubic millimeter) from a series of controls for immunotoxin structure and function. Values are \pm SEM. Significance $=p<0.05$. Note that only free saporin affected cholinergic amacrine cell number, reducing the number of cells $\sim 30 \%\left({ }^{*} p<0.001\right)$.

decreased $\sim 14 \%$ (both $p<0.001$ ), but the two injected groups did not differ from each other. Injection of vehicle reduced the thickness relative to normal of the ONL $(\sim 9 \% ; p=0.011)$, the OPL $(\sim 24 \% ; p<0.001)$, and the IPL $(\sim 8 \% ; p=0.015)$, but not the INL or the ganglion cell layer (GCL). Toxin treatment reduced the thickness relative to normal of the ONL $(\sim 12 \% ; p=$ $0.006)$, the OPL $(\sim 26 \% ; p<0.001)$, the IPL $(\sim 14 \% ; p=0.001)$, and the GCL $(\sim 12 \% ; p=0.014)$, but not the INL. Only the thickness of the IPL was different between vehicle- and immunotoxin-treated retinas. The immunotoxin decreased the thickness of this synaptic layer by $\sim 6 \%(p=0.018)$.

To assess the cell specificity of the immunotoxin, counts were
Table 1. Effects of the immunotoxin on non-cholinergic cells

\begin{tabular}{llll} 
Marker & Vehicle & Immunotoxin & $p$ value \\
\hline $\begin{array}{l}\text { DAPI nuclei in } \\
\text { the GCL }\end{array}$ & $562,918 \pm 23,594$ & $566,352 \pm 9614$ & 0.899 \\
$\begin{array}{l}\text { Recoverin } \\
\text { Parvalbumin in } \\
\text { the GCL }\end{array}$ & $217,962 \pm 12,076$ & $213,516 \pm 13,808$ & 0.820 \\
$\begin{array}{l}\text { Parvalbumin in } \\
\text { the INL }\end{array}$ & $49,527 \pm 7143$ & $39,017 \pm 6789$ & 0.267 \\
$\begin{array}{l}\text { Tyrosine } \\
\text { hydroxylase }\end{array}$ & $138,236 \pm 7015$ & $110,686 \pm 8468$ & 0.066 \\
$\begin{array}{l}\text { Calbindin } \\
\text { Calbin }\end{array}$ & $51,792 \pm 1075$ & $55,572 \pm 9441$ & 0.711 \\
\hline
\end{tabular}

Counts of noncholinergic cells in the inner retina from vehicle-injected and toxin (70 $\mathrm{ng} / \mu \mathrm{l})$-injected retinas. The cell types labeled with each marker are described in Materials and Methods. Values are again mean \pm SEM. Note that there were no significantly different cell counts between vehicle-treated and toxin-treated retinas.

made of the total number of cells (labeled by DAPI) in the ganglion cell layer. This provided a measure of the entire ganglion cell population as well as all displaced amacrine cells. Counts were also made of parvalbumin-positive cells in the GCL, which includes ganglion cells and a small subset of AII amacrine cells (Uesugi et al., 1992; Wässle et al., 1993), recoverin-positive cone bipolar cells (Milam et al., 1993; Euler and Wässle, 1995), and parvalbumin-positive amacrine cells in the IPL; tyrosine hydroxylase-positive dopaminergic amacrine cells (Dacey, 1990; Kolb et al., 1991), as well as calbindin-positive amacrine cells. The resulting cell counts are shown in Table 1. As may be seen, all of the cell populations that we assessed did not differ significantly in the vehicle-treated and toxin-treated retinas.

\section{Bipolar cell inputs in the absence of cholinergic amacrine cells}

Having established the effectiveness and specificity of the cholinergic cell immunotoxin, we next sought to determine whether the early depletion of cholinergic amacrine cells disrupts the subsequent development of cone bipolar cell projections.

Figure 6 shows developing retinas, double-labeled with recoverin for cone bipolar cells (green) and VAChT for cholinergic amacrine cells (red), that were treated on P1 with toxin or with 

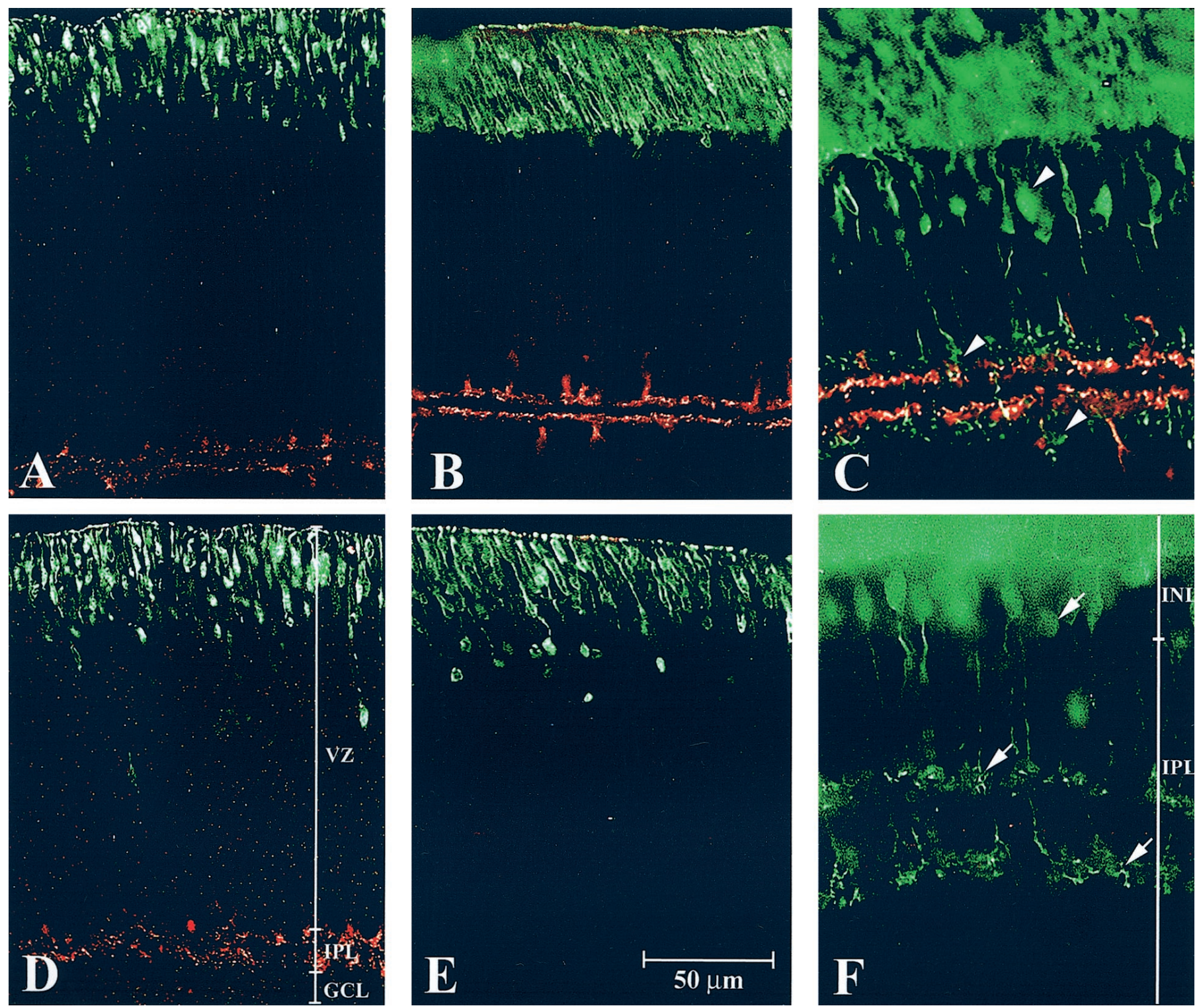

Figure 6. Cone bipolar cell in-growth proceeds normally. $A-F$ are P1-injected rat retinas double labeled with recoverin ( green) and VAChT (red) killed at $\mathrm{P} 2(A, D), \mathrm{P} 6(B, E)$, and $\mathrm{P} 12(C, F)$. The top images are vehicle-injected retinas, and the bottom images are toxin-injected retinas. Note the similarities between the staining pattern in the top series of panels and those in Figures 1 and 2, and that the stratification of cholinergic amacrine cells precedes the migration of cone bipolar cells. Note also that, even in the complete absence of VAChT immunoreactivity, cone bipolar cell somas migrate from the ventricular zone $(E)$ and extend their axons to two distinct strata in the IPL $(F)$, much as do cells in vehicle-treated retinas.

vehicle (PBS). After the complete elimination of cholinergic amacrine cells (as indicated by a complete absence of VAChT labeling), cone bipolar cells, visualized by labeling with the antibody against recoverin, appeared to migrate from the ventricular zone, extend their axons into the IPL, and form two distinct On and Off strata within this synaptic layer. The time course of these developmental events is indistinguishable from that observed in normal or vehicle control-treated retinas (Fig. 6, compare with Fig. 2).

Figure 7 provides another illustrative example of this finding for a P12 retina double labeled with recoverin (green) and VAChT (red). The top panels show vehicle-injected retinas, and the bottom panels show toxin-injected retinas. The two lowmagnification panels on the left indicate that the general morphology of the retina, particularly that of the cone bipolar cells, is unaffected by immunotoxin treatment. In the higher-magnification images on the right, bipolar cell axon arbors appear not to be altered by the loss of cholinergic amacrine cells. Note that On cone bipolar cells terminate on the outer side of the amacrine layer (arrows), whereas Off cone bipolar cells terminate on the inner side of the amacrine layer (arrowheads). It is striking that even in the complete absence of their amacrine cell targets, the axon terminals of On and Off cone bipolar cells attain a stratified state, indistinguishable from that found in the normal retina.

\section{DISCUSSION}

There are two principal components to the present study: the construction of a novel immunotoxin designed to selectively kill cholinergic neurons, and the use of this toxin to determine whether cholinergic amacrine cells play a role in the segregation of recoverin-positive $\mathrm{On}$ and Off cone bipolar cell projections. Below we consider each of these issues. 

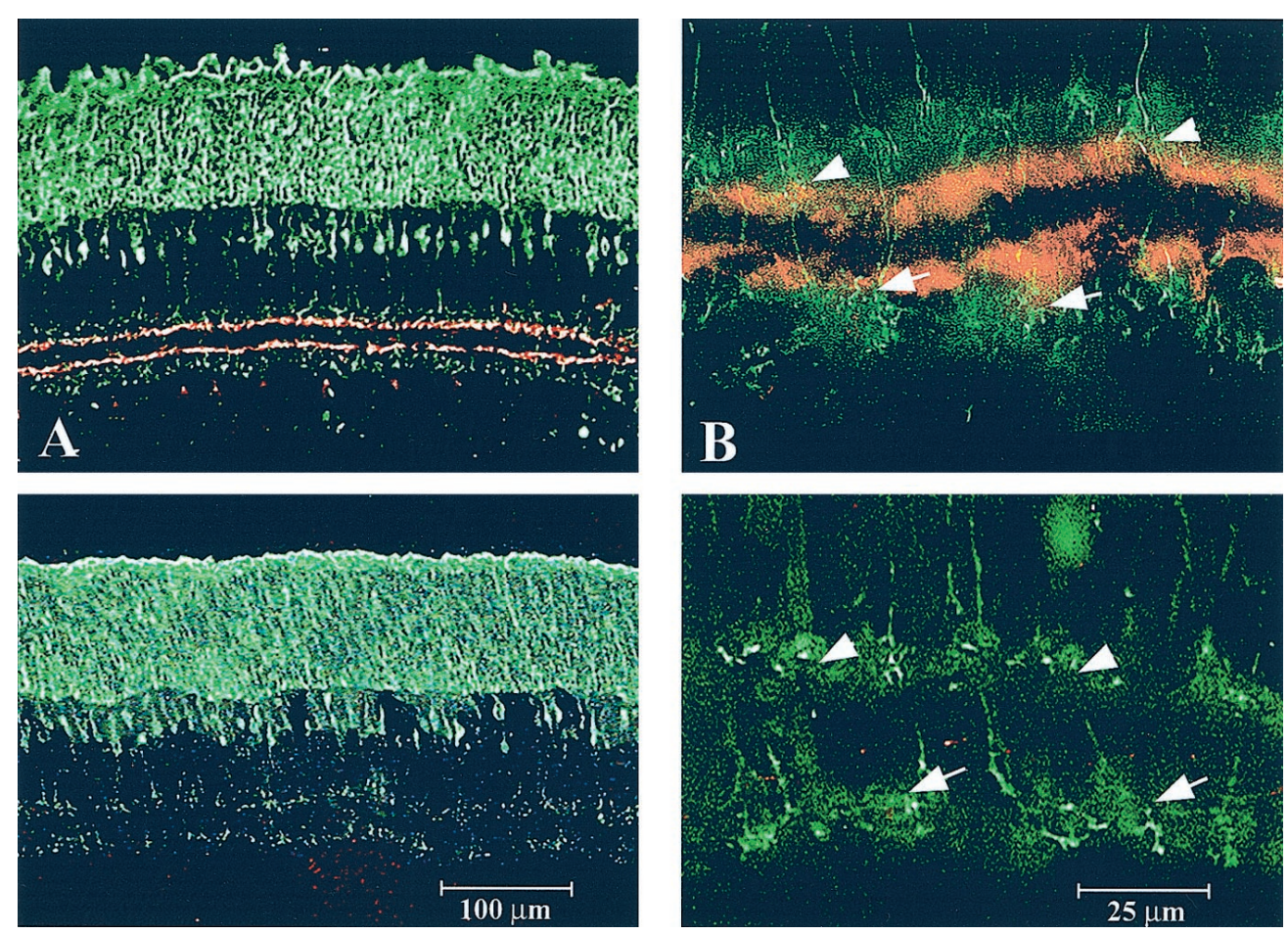

Figure 7. Axonal targeting of bipolar cells is tightly controlled. Shown are retinal cross sections with the GCL at the bottom, double immunostained with anti-recoverin for cone bipolar cells (green) and with anti-VAChT for cholinergic amacrine cells (red). The top panels are vehicle-injected retinas, and the bottom panels are toxin-injected retinas. The two low-magnification panels on the left show that the general morphology of the retina, particularly that of the cone bipolar cells, is unaffected by toxin treatment. The higher-magnification images on the right show that fine cone bipolar cell structures and axonal targeting are also primarily unaffected by the loss of cholinergic amacrine cells. Arrows show On bipolar terminals in the inner portion of the IPL, and arrowheads show Off bipolar terminals in the outer IPL.

\section{A new immunotoxin for elimination of cholinergic neurons}

The ability to deplete specific populations of neurons enables neurobiologists to study the involvement of different cell types in the functional and structural organization of the mature and developing nervous system. Several different methods have been devised for this purpose, including photoablation (He and Masland, 1997) and systemic administration of excitatory neurotransmitters (Johnson and Reese, 2000), as well as the administration of immunotoxins directed at specific surface proteins expressed by targeted neurons (Wiley, 1996; Wiley and Lappi, 1997; Youle and Neville, 1980; Flavell, 1998; Yoshida et al., 2001).

The toxins currently used for eliminating cholinergic cells, however, have severe shortcomings that limit their usefulness for retinal research. For instance, the AF64A toxin has been found to induce nonspecific damage both in the retina as well as at other levels of the CNS (McGurk et al., 1987; Chrobak et al., 1988; Estrada et al., 1988; Gómez-Ramos et al., 1990). More recently, complete and apparently specific depletion of cholinergic amacrine cells from mouse retina (Yoshida et al., 2001) has been achieved using immunotoxin-mediated cell targeting (Kobayashi et al., 1995). A limitation of this elegant approach is that it requires transgenic animals, which currently limits its application to mice. Perhaps the most widely used immunotoxin to date is 192 IgG-saporin (Wiley et al., 1991; Leanza et al., 1995, 1996a,b; Waite et al., 1995; Pizzo et al., 1999), which is directed against the low-affinity NGF receptor (p75) expressed by cholinergic neurons in the basal forebrain (Batchelor et al., 1989; Yan and Johnson, 1989). Unfortunately, 192 IgG-saporin lacks selectivity toward cholinergic amacrine cells because the p75 receptor is expressed by some ganglion cells as well as Muller glial cells (Schatteman et al., 1988; Yan and Johnson, 1988; Carmignoto et al., 1989; Carmignoto et al., 1991; Ugolini et al., 1995; Hu et al., 1998; Suzuki et al., 1998).

The foregoing considerations motivated us to construct a new immunotoxin, anti-VAChT::saporin, which would be internalized only by cholinergic neurons, leading to their rapid elimination by translational arrest of protein synthesis. The prevalence of many amino acid residues with both amino and carboxyl groups in both IgG and saporin molecules suggested EDC as an effective immunotoxin cross-linking agent, and a mass ratio analysis indicated that approximately six saporin molecules could be attached to a single IgG molecule without steric hindrance. The length of the EDC reaction was optimized to minimize multimerization of the anti-VAChT::saporin complex.

The results demonstrate that the immunotoxin that we constructed provides a means for achieving relatively rapid, selective, and complete depletion of cholinergic neurons. Even after a single intraocular injection at relatively low doses, virtually all the cholinergic amacrine cells were eliminated within a period of 48 hr. By comparison, other immunotoxins have been reported to take much longer to destroy cells: in some cases, as much as $14 \mathrm{~d}$ after treatment (Martin et al., 1999). With respect to the specificity of the effects, counts of several noncholinergic cell populations in the ganglion cell and in the inner nuclear layers showed that their numbers were within normal limits. At very high doses of the immunotoxin, however, we observed nonspecific damage to the developing retina. It is also worth noting that injections of the immunotoxin into the basal forebrain of the adult rat caused a massive loss of cholinergic neurons. Thus, the immunotoxin that we have constructed should prove useful in studies requiring depletion of cholinergic cells at all levels of the nervous system.

\section{Mechanisms of immunotoxin action}

The specific depletion of cholinergic neurons observed in the present study suggests that saporin conjugated to the VAChT antibody selectively targeted this class of neurons. At the same time, it should be stressed that the mechanism by which the toxin gets incorporated into and selectively kills cholinergic cells remains to be established. The anti-VAChT antibody used to target saporin to cholinergic amacrine cells is directed to a synthetic peptide representing the last 20 amino acids of the $C$ terminus of 
VAChT (CSPPGPFDGCEDDYNYYSRS; Chemicon International). The current paradigm of the structure of the vesicular amine transporter (VAT) family, which includes VAChT and the vesicular monoamine transporters (VMAT1 and VMAT2), is based on projections from cDNA sequences (Erickson et al., 1994; Roghani et al., 1994). This analysis suggests that the VAT family of proton-anti-porter transporters contains 12 hydrophobic membrane-spanning domains, made up of 1 central domain surrounded by a ring formed by the remaining 11 . The sequencebased projections also place both the amino and $\mathrm{C}$ terminals of the VAT proteins in the cytosol. Direct evidence in support of this proposed orientation for VAT proteins is yet to be provided (Parsons, 2000).

Immunotoxins targeted to proteins, such as surface receptors, that are nonrecycling (or inefficiently recycled) show decreased toxicity attributable to lysosomal activity (Davol et al., 1999). Recycling of cholinergic vesicles involves exposure of the luminal components, including those of VAChT, at the cell surface during fusion with the plasma membrane (Matteoli et al., 1992). Both protein and membrane components are then recycled and reused by clathrin-dependent endocytosis via an endosomal compartment (De Camilli and Jahn, 1990; Hannah et al., 1999). Even if the $\mathrm{C}$ terminus of the VAChT protein is not exposed at the cell surface during ACh release, its presence in the early endosomal compartment could direct the immunotoxin conjugate to a nonlysosomal pathway, allowing the toxin to be released in an active form. Thus, the specific targeting of cholinergic neurons seen with anti-VAChT::saporin may be dependent on the separation of vesicular recycling pathways from those of lysosomal degradation.

\section{Formation of On and Off cone bipolar projections is not dependent on cholinergic amacrine cells}

We have demonstrated in the present study that cholinergic amacrine cells can be recognized very early in development and that their stratified processes are clearly evident by $2 \mathrm{~d}$ after birth. These observations on the rat retina (cf. Koulen, 1997) are consistent with the results of studies on a number of other species showing that cholinergic amacrine cells are among the earliest retinal neurons to become differentiated (for review, see Zhou, 2001). Of particular relevance here is the relatively long delay $(\sim 10 \mathrm{~d})$ between the appearance of the two strata of cholinergic processes and the in-growth of cone bipolar cells axons. This developmental sequence, as well as our previous finding that On and Off cone bipolar cell pathways form after total depletion of retinal ganglion cells (Günhan-Agar et al., 2000), leads to the suggestion that cholinergic amacrine cells might play a key role in the formation of segregated bipolar cell pathways. The construction of the cholinergic immunotoxin enabled us to directly test this hypothesis. The results show clearly and unequivocally that recoverin-positive On and Off bipolar cells are not dependent on cholinergic amacrine cells for the segregation of their axon terminals into two distinct strata.

What, then, might account for the segregation of On and Off cone bipolar cell axons? One possibility is that the presence of one or the other target population of bipolar cells (i.e., ganglion cells or cholinergic amacrine cells) is sufficient to provide a signal for the directed outgrowth of bipolar cell axons. Thus, if either cell population remains intact, cone bipolar cell pathways would still form normally. The merits of this idea could be tested in future studies by examining the effects of eliminating both ganglion cells as well as cholinergic amacrine cells. Still other possible guidance mechanisms might include intrinsic factors ex- pressed by developing bipolar cells as well as the differential distribution of signal molecules in the extracellular matrix (cf. Pearlman and Sheppard, 1996). These retinal interneurons may well offer an unparalleled opportunity for furthering our understanding of the formation of nonspiking local circuits within the mammalian brain.

Cone bipolar cells have been classified into several different types on the basis of their salient morphological (Euler and Wässle, 1995) and functional (DeVries, 2000) properties. In the present study we have focused on recoverin-positive On and Off cone bipolar cells, two of the nine types that have been distinguished in the rat retina (Euler and Wässle, 1995). This choice was based on the specificity of recoverin labeling of On and Off cone bipolar cells (Milam et al., 1993), as well as our previous finding that the stratification of the axonal terminals of these interneurons is established in the absence of ganglion cells (Günhan-Agar et al., 2000). Although it has been reported that $>80 \%$ of the synapses formed by recoverin-positive cone bipolar cells are with amacrine cells (Chun et al., 1999), whether these include the processes of cholinergic cells remains to be resolved. The types of bipolar cell that form synapses with the stratified processes of cholinergic amacrine cells also remain to be fully documented (Famiglietti, 1983; Linn et al., 1991; Brown and Masland, 1999). Such information, when it becomes available, could shed important insights into the remarkable ability of recoverin-positive On and Off cone bipolar cells to form their stratified projection patterns in the absence of either retinal ganglion cells (Günhan-Agar et al., 2000) or cholinergic amacrine cells.

\section{REFERENCES}

Batchelor PE, Armstrong DM, Blaker SN, Gage FH (1989) Nerve growth factor receptor and choline acetyltransferase colocalization in neurons within the rat forebrain: response to fimbria-fornix transection. J Comp Neurol 284:187-204.

Bisti S, Gargini C, Chalupa LM (1998) Blockade of glutamate-mediated activity in the developing retina perturbs the functional segregation of ON and OFF pathways. J Neurosci 18:5019-5025.

Bodnarenko SR, Chalupa LM (1993) Stratification of ON and OFF ganglion cell dendrites depends on glutamate-mediated afferent activity in the developing retina. Nature 364:144-146.

Bodnarenko SR, Jeyarasasingam G, Chalupa LM (1995) Development and regulation of dendritic stratification in retinal ganglion cells by glutamate-mediated afferent activity. J Neurosci 15:7037-7045.

Brown SP, Masland RH (1999) Costratification of a population of bipolar cells with the direction-selective circuitry of the rabbit retina. J Comp Neurol 408:97-106.

Carmignoto G, Maffei L, Candeo P, Canella R, Comelli C (1989) Effect of NGF on the survival of rat retinal ganglion cells following optic nerve section. J Neurosci 9:1263-1272.

Carmignoto G, Comelli MC, Candeo P, Cavicchioli L, Yan Q, Merighi A, Maffei L (1991) Expression of NGF receptor and NGF receptor mRNA in the developing and adult rat retina. Exp Neurol 111:302-311.

Chalupa LM, Jeyarasasingam G, Snider CJ, Bodnarenko SR (1998) Development of On and Off retinal ganglion cell mosaics. In: Development and organization of the retina from molecules to function (Chalupa LM, Finlay BL, eds), pp 77-91, New York: Plenum.

Chrobak JJ, Hanin I, Schmechel DE, Walsh TJ (1988) AF64A-induced working memory impairment: behavioral, neurochemical and histological correlates. Brain Res 463:107-117.

Chun M-H, Kim I-B, Oh S-J, Chung J-W (1999) Synaptic connectivity of two types of recoverin-labeled cone bipolar cells and glutamic acid decarboxylase immunoreactive amacrine cells in the inner plexiform layer of the rat retina. Vis Neurosci 16:791-800.

Dacey DM (1990) The dopaminergic amacrine cell. J Comp Neurol 301:461-489.

Davis MT, Preston JF (1981) A simple modified carbodiimide method for conjugation of small-molecular-weight compounds to immunoglobulin $\mathrm{G}$ with minimal protein crosslinking. Anal Biochem 116:402-407.

Davol PA, Bizuneh A, Frackelton AR (1999) Wortmannin, a phosphoinositide 3-kinase inhibitor, selectively enhances cytotoxicity of receptor-directed-toxin chimeras in vitro and in vivo. Anticancer Res 19:1705-1713.

De Camilli P, Jahn R (1990) Pathways to regulated exocytosis in neurons. Annu Rev Physiol 52:625-645. 
DeVries SH (2000) Bipolar cells use kainate and AMPA receptors to filter visual information into separate channels. Neuron 28:847-856.

Erickson JD, Varoqui H, Schafer MKH, Modi W, Diebler MF, Weihe E, Rand JB, Eiden LE, Bonner TI, Usdin TB (1994) Functional identification of a vesicular acetylcholine transporter and its expression from a "cholinergic" gene locus. J Biol Chem 269:21929-21932.

Estrada C, Triguero D, Martin del Río R, Gomez-Ramos P (1988) Biochemical and histological modifications of the rat retina induced by the cholinergic neurotoxin AF64A. Brain Res 439:107-115.

Euler T, Wässle H (1995) Immunocytochemical identification of cone bipolar cells in the rat retina. J Comp Neurol 361:461-478.

Famiglietti Jr EV (1983) On and On-Off pathways through amacrine cells in mammalian retina: the synaptic connections of "starburst" amacrine cells. Vision Res 23:1265-1279.

Famiglietti Jr EV (1991) Synaptic organization of starburst amacrine cells in rabbit retina: analysis of serial thin section by electron microscopy and graphic reconstruction. J Comp Neurol 309:40-70.

Famiglietti Jr EV (1992) Dendritic co-stratification of On and On-Off directionally selective ganglion cells with starburst amacrine cells in rabbit retina. J Comp Neurol 324:322-335.

Famiglietti Jr EV, Kolb H (1976) Structural basis for On- and Off-center responses in retinal ganglion cells. Science 194:193-195.

Feller MB, Wellis DP, Stellwagen D, Werblin FS, Shatz CJ (1996) Requirement for cholinergic synaptic transmission in the propogation of spontaneous retinal waves. Science 272:1182-1187.

Flavell DJ (1998) Saporin immunotoxins. Curr Top Microbiol Immunol 234:57-61.

Gómez-Ramos P, Galea E, Estrada C (1990) Neuronal and microvascular alterations induced by the cholinergic toxin AF64A in the rat retina. Brain Res 520:151-158.

Günhan-Agar E, Kahn D, Chalupa LM (2000) Segregation of On and Off bipolar cell axonal arbors in the absence of retinal ganglion cells. J Neurosci 20:306-314.

Hannah MJ, Schmidt AA, Huttner WB (1999) Synaptic vesicle biogenesis. Annu Rev Cell Dev Biol 15:733-798.

He S, Masland RH (1997) Retinal direction selectivity after targeted laser ablation of starburst amacrine cells. Nature 389:378-382.

Hu B, Yip HK, So KF (1998) Localization of p75 neurotrophin receptor in the retina of the adult SD rat: an immunocytochemical study at light and electron microscopic levels. Glia 24:187-197.

Hutsler JJ, Chalupa LM (1995) The development of neuropeptide Y immunoreactive amacrine and ganglion cells in the pre- and postnatal cat retina. J Comp Neurol 361:152-164.

Johnson PT, Reese BE (2000) Cholinergic amacrine cells and retinal ganglion cells are necessary for stratification of rod terminals in the inner plexiform layer during development. Invest Ophthalmol Vis Sci 41:4507.

Kobayashi K, Morita S, Sawada H, Mizuguchi T, Yamada K, Nagatsu I, Fujita K, Kreitman RJ, Pastan I, Nagatsu T (1995) Immunotoxinmediated conditional disruption of specific neurons in transgenic mice. Proc Natl Acad Sci USA 92:1132-1136

Kolb H, Cuenca N, Dekorver L (1991) Postembedding immunocytochemistry for GABA and glycine reveals the synaptic relationships of the dopaminergic amacrine cell of the cat retina. J Comp Neurol 310:267-284.

Koulen P (1997) Vesicular acetylcholine transporter (VAChT): a cellular marker in rat retinal development. NeuroReport 8:2845-2848.

Leamey CA, Cramer KS, Sur M (1998) The role of activity-dependent mechanisms in pattern formation in the retinogeniculate pathway. In: Development and organization of the retina from molecules to function (Chalupa LM, Finlay BL, eds), pp 319-328. New York: Plenum.

Leanza G, Nilsson OG, Wiley RG, Björklund A (1995) Selective lesioning of the basal forebrain cholinergic system by intraventricular 192 IgG-saporin: behavioral, biochemical and stereological studies in the rat. Eur J Neurosci 7:329-343.

Leanza G, Nikkhah G, Nilsson OG, Wiley RG, Björklund A (1996a) Extensive reinnervation of the hippocampus by embryonic basal forebrain cholinergic neurons grafted into the septum of neonatal rats with selective cholinergic lesions. J Comp Neurol 373:355-357.

Leanza G, Nilsson OG, Nikkhah G, Wiley RG, Björklund A (1996b) Effects of neonatal lesions of the basal forebrain cholinergic system by 192 immunoglobulin G-saporin: biochemical, behavioral and morphological characterization. Neuroscience 74:119-141.

Linn DM, Blazynski C, Redburn DA, Massey SC (1991) Acetylcholine release from the rabbit retina mediated by kainate receptors. J Neurosci 11:111-122.

Martin WJ, Gupta NK, Loo CM, Rhode DS, Bausbaum AI (1999) Differential effects of neurotoxic destruction of descending noradrenergic pathways on acute and persistent nociceptive processing. Pain 80:57-65

Maslim J, Stone J (1988) Time course of stratification of the dendritic fields of ganglion cells in the retina of the cat. Dev Brain Res 44:87-93.

Matteoli M, Takei K, Perin MS, Sudhof TC, De Camilli P (1992) Exoendocytotic recycling of synaptic vesicles in developing processes of cultured hippocampal neurons. J Cell Biol 117:849-861.
McGurk SR, Hartgraves SL, Kelly PH, Gordon MN, Butcher LL (1987) Is ethylcholine mustard aziridinium ion a specific cholinergic neurotoxin? Neuroscience 22:215-224.

Milam AH, Dacey DM, Dizhoor AM (1993) Recoverin immunoreactivity in mammalian cone bipolar cells. Vis Neurosci 10:1-12.

Miller ED, Tran M-N, Wong G-K, Oakley DM, Wong ROL (1999) Morphological differentiation of bipolar cells in the ferret retina. Vis Neurosci 16:1133-1144.

Nakajima N, Ikada Y (1995) Mechanism of amide formation by carbodiimide for bioconjugation in aqueous media. Bioconjug Chem 6:123-130.

Nelson R, Famigletti Jr EV, Kolb H (1978) Intracellular staining reveals different levels of stratification for On- and Off-center ganglion cells in cat retina. J Neurophysiol 41:472-483.

Parsons SM (2000) Transport mechanisms in acetylcholine and monoamine storage. FASEB J 14:2423-2434.

Pearlman AL, Sheppard AM (1996) Extracellular matrix in early cortical development. Prog Brain Res 108:117-134.

Pizzo DP, Waite JJ, Thal LJ, Winkler J (1999) Intraparenchymal infusions of 192 IgG-saporin: development of a method for selective and discrete lesioning of cholinergic basal forebrain nuclei. J Neurosci Methods 91:9-19.

Redburn DA, Rowe-Redleman C (1996) Developmental neurotransmitters. Signals for shaping neuronal circuitry. Invest Ophthalmol Vis Sci 37:1479-1482.

Roghani A, Feldman J, Kohan SA, Shirzadi A, Gunderson CB, Brecha N, Edwards RH (1994) Molecular cloning of a putative vesicular transporter for acetylcholine. Proc Natl Acad Sci USA 91:10620-10624.

Schatteman GC, Gibbs L, Lanahan AA, Claude P, Bothwell M (1988) Expression of NGF receptor in the developing and adult primate central nervous system. J Neurosci 8:860-873.

Singer W (1995) Development and plasticity of cortical processing architectures. Science 270:758-764.

Suzuki A, Nomura S, Morii E, Fukuda Y, Kosaka J (1998) Localization of mRNAs for trkB isoforms and p75 in rat retinal ganglion cells. J Neurosci Res [Erratum (1999) 55:135] 54:27-37.

Uesugi R, Yamada M, Mizuguchi M, Baimbridge KG, Kim SU (1992) Calbindin D-28k and parvalbumin immunohistochemistry in developing rat retina. Exp Eye Res 54:491-499.

Ugolini G, Cremisi F, Maffei L (1995) TrkA, TrkB and p75 mRNA expression is developmentally regulated in the rat retina. Brain Res 704:121-124.

Waite JJ, Chen AD, Wardlow ML, Wiley RG, Lappi DA, Thal LJ (1995) 192 immunoglobulin G-saporin produces graded behavioral and biochemical changes accompanying the loss of cholinergic neurons of the basal forebrain and cerebellar Purkinje cells. Neuroscience 65:463-476.

Wang G-Y, Liets LC, Chalupa LM (2001) Unique functional properties of $\mathrm{On}$ and Off pathways in the developing mammalian retina. J Neurosci 21:4310-4317.

Wässle H, Grunert U, Rohrenbeck J (1993) Immunocytochemical staining of AII-amacrine cells in the rat retina with antibodies against parvalbumin. J Comp Neurol 332:407-420.

White CA, Chalupa LM (1991) A subgroup of alpha ganglion cells in the adult cat retina is immunoreactive for somatostatin. J Comp Neurol 304:1-13.

Wiesel TN (1982) Postnatal development of the visual cortex and the influence of the environment. Nature 299:583-592.

Wiley RG (1996) Targeting toxins to neural antigens and receptors. Semin Cancer Biol 7:71-77.

Wiley RG, Lappi DA (1997) Destruction of neurokinin-1 receptor expressing cells in vitro and in vivo using substance P-saporin in rats Neurosci Lett 230:97-100.

Wiley RG, Oeltmann TN, Lappi DA (1991) Immunolesioning: selective destruction of neurons using immunotoxin to rat NGF receptor. Brain Res 562:149-153.

Yan Q, Johnson EM (1988) An immunohistochemical study of the nerve growth factor receptor in developing rats. J Neurosci 8:3481-3498.

Yan Q, Johnson EM (1989) Immunohistochemical localization and biochemical characterization of nerve growth factor receptor in adult rat brain. J Comp Neurol 290:585-598.

Yoshida K, Watanabe D, Ishikane H, Tachibana M, Pastan I, Nakanishi S (2001) A key role of starburst amacrine cells in originating retinal directional selectivity and optokinetic eye movement. Neuron 30:771-780

Youle RJ, Neville DM (1980) Anti-Thy 1.2 monoclonal antibody linked to ricin is a potent cell-type-specific toxin. Proc Natl Acad Sci USA 77:5483-5486.

Zhou ZJ (1998) Direct participation of starburst amacrine cells in spontaneous rhythmic activities in the developing mammalian retina. J Neurosci 18:4155-4165.

Zhou ZJ (2001) The function of the cholinergic system in the developing mammalian retina. Prog Brain Res 131:599-614.

Zhou ZT, Zhoa D (2000) Coordinated transitions in neurotransmitter systems for the initiation and propagation of spontaneous retinal waves. J Neurosci 20:6570-6577. 